\title{
MEWUJUDKAN KESADARAN HUKUM TERHADAP KEKERASAN DALAM RUMAH TANGGA BAGI PEREMPUAN DAN ANAK DI PULAU SERAM
}

\author{
Patrick Corputty ${ }^{1}$, Astuti Nur Fadillah $\mathbf{M}^{2}$ \\ ${ }^{1,2)}$ Program Studi Ilmu Hukum, Fakultas Hukum, Universitas Pattimura \\ e-mail: corputtyp@gmail.com
}

\begin{abstract}
Abstrak
Kekerasan dalam rumah tangga saat ini semakin menunjukkan kompleksitasnya, bahkan setiap tahunnya menunjukkan angka peningkatan kasus, seperti layaknya fenomena gunung es. Kekerasan dalam rumah tangga yang terjadi pada perempuan dan anak seringkali menjadi masalah yang tidak bisa diselesaikan dengan baik oleh pemerintah. Perempuan dan anak sebagai suatu kelompok dalam masyarakat harus terjamin hak-hak yang dimilikinya secara asasi dalam hukum yang kuat dan konsisten. segala bentuk kekerasan yang dialami oleh perempuan dan anak dapat memberikan dampak pada kehidupan mereka oleh karena itu diperlukan penanganan yang tepat sehingga dapat membantu mereka untuk hidup tenang dan bebas dari segala perlakukan kekerasan. Metode yang digunakan dalam pengabdian masyarakat ini yaitu penyuluhan serta konseling hukum bagi perempuan dan anak dipulau seram. Kami berharap kegiatan ini dapat memberikan dampak yang positif dengan berkurangnya tindak kekerasan yang terjadi kepada perempuan dan anak dalam keluarga.
\end{abstract}

Kata Kunci: Kesadaran Hukum, Kekerasan, Perempuan, Anak

\begin{abstract}
Domestic violence is currently increasingly showing its complexity, even every year it shows an increasing number of cases, like an iceberg phenomenon. Domestic violence that occurs to women and children is often a problem that cannot be solved properly by the government. Women and children as a group in society must be guaranteed their human rights in a strong and consistent law. all forms of violence experienced by women and children can have an impact on their lives, therefore proper handling is needed so that it can help them to live calmly and free from all violent treatment. The method used in this community service is counseling and legal counseling for women and children on the island of Seram. We hope that this activity can have a positive impact by reducing acts of violence against women and children in the family.
\end{abstract}

Keywords: Legal Awareness, Violence, Women, Children

\section{PENDAHULUAN}

Kekerasan dalam Rumah Tangga adalah setiap perbuatan terhadap seseorang terutama perempuan, yang berakibat timbulnya kesengsaraan atau penderitaan secara fisik, seksual, psikologis, dan/ atau penelantaran rumah tangga termasuk ancaman untuk melakukan perbuatan, pemaksaan, dan perampasan kemerdekaan secara melawan hukum dalam lingkup rumah tangga. Kekerasan dalam rumah tangga sebenarnya bukan merupakan hal yang baru. Selama ini selalu dirahasiakan atau ditutup-tutupi oleh keluarga maupun oleh korban sendiri. Kekerasan dalam rumah tangga merupakan suatu permasalahan dalam keluarga. Kekerasan Dalam Rumah Tangga(KDRT) bisa menimpa siapa saja termasuk isteri dan anak.

Setiap pasangan yang menikah memiliki impian untuk membangun keluarga bahagia, penuh kasih sayang, dan saling mencintai secara lahir maupun batin. Namun, pada kenyataannya tidak semua pernikahan dan rumah tangga berjalan harmonis sesuai dengan yang dicita citakan. Dalam perjalanan perkawinan, pasangan suami isteri tidak selalu dan tidak sepenuhnya dapat merasakan kebahagiaan, 
saling mencintai, dan saling menyayangi, melainkan terkadangan muncul rasa ketidaknyamanan, tertekan, kesedihan, saling takut, serta benci di antara pasangan. Hal ini diindikasikan dengan masih dijumpainya sejumlah rumah tangga yang bermasalah.

Permasalahan kekerasan dalam rumah tangga saat ini semakin menunjukkan kompleksitasnya, bahkan setiap tahunnya menunjukkan angka peningkatan kasus, seperti layaknya fenomena gunung es. Menurut Pasal 1 UU No. 23 Tahun 2004 tentang penghapusan kekerasan dalam rumah tangga, definisi kekerasan dalam rumah tangga adalah setiap perbuatan terhadap seseorang terutama perempuan, yang berakibat timbulnya kesengsaraan atau penderitaan secara fisik, seksual, psikologis dan atau penelantaran rumah tangga termasuk ancaman untuk melakukan perbuatan, pemaksaan, atau perampasan kemerdekaan secara melawan hukum dalam lingkup rumah tangga.

Kekerasan dalam rumah tangga sangat erat kaitannya dengan ketiadaan akses perempuan kepada sumber daya ekonomi (financial modal dan benda-benda tidak bergerak seperti tanah, dan sumber-sumber kesejahteraan lain), usia, pendidikan, agama dan suku bangsa. Kekerasan Dalam Rumah Tangga (KDRT) yang dialami perempuan dan anak bisa lebih dari satu bentuk kekerasan baik secara fisik, psikologis, seksual dan ekonomi.

Selain itu segala bentuk kekerasan yang dialami oleh perempuan maupun anak akan memberikan dampak pada kehidupan mereka oleh karena itu diperlukan penanganan yang tepat sehingga dapat membantu mereka untuk hidup tenang dan bebas dari segala perlakukan kekerasan. Kekerasan dalam rumah tangga merupakan suatu masalah global yang hadir di semua budaya dan masyarakat. Siapapun dapat menjadi korban kekerasan dalam rumah tangga dan umumnya disebabkan karena relasi kuasa (ketidakseimbangan kekuasaan) dan control.

Berdasarkan uraian tersebut maka yang menjadi judul dalam kegiatan pengabdian masyarakat yaitu mewujdukan kesadaran hukum terhadap kekerasan dalam rumah tangga bagi perempuan dan anak. Adapun tujuan kegiatan pengabdian kepada masyarakat ini diharapakan dapat memberikan pengetahuan tentang kesadaran hukum kepada perempuan dan anak dari tindakan kekerasan yang terjadi dalam rumah tangga.

\section{METODE}

Kegiatan pengabdian kepada masyarakat yang dilaksanakan di Pulau Seram merupakan sebuah kegiatan pengabdian masyarakat yang dilakukan dengan beberapa tahapan yaitu:

a. Melakukan identifikasi masalah yang ada pada pulau seram.

b. Mengidentifikasi jumlah kasus kekerasan yang terjadi kepada perempuan dan anak.

c. Memberikan penyuluhan tentang Perlindungan hukum terhadap kekerasan dalam rumah tangga bagi perempuan dan anak di pulau seram.

Kegiatan pengabdian kepada masyarakat di Pulau Seram adalah metode penyuluhan hukum tentang kesadaran hukum terhadap kekerasan dalam rumah tangga bagi perempuan dan anak di pulau seram.

\section{HASIL DAN PEMBAHASAN}

Kekerasan dalam rumah tangga terjadi pada semua lapisan sosial masyarakat maupun latar belakang pendidikan. Hal ini menunjukkan bahwa kekerasan terhadap perempuan bukanlah disebabkan oleh situasi ekonomi atau tinggi rendahnya pendidikan seseorang, tetapi lebih pada ketidaksetaraan kekuasaan antara laki-laki dan perempuan. Pembagian peran sosial terjadap perempuan dan laki-laki menyebabkan terjadinya ketidaksamaan dan ketidakadilan terhadap perempuan. Pembagian peran sosial menempatkan perempuan hanya boleh berada di ranah domestik(keluarga), sedangkan laki-laki di ranah publik (lingkungan), dapat menyebabkan timbulnya ketimpangan dan ketidaksejajaran. Bentuk kekerasan dalam rumah tangga antara lain:

a. Kekerasan Fisik, Kekerasan fisik merupakan perbuatan yang mengakibatkan rasa sakit, jatuh sakit atau luka berat. Terdapat beberapa jenis kekerasan yang dapat digolongkan sebagai kekerasan fisik, antara lain adalah dipukul, dilempar dengan barang, dijambak rambutnya, ditendang, dan sebagainya. 
b. Kekerasan Seksual, tindakan kekerasan seksual yang perempuan menyerahkan dirinya meski dalam keadaan terpaksa dan dalam ancaman seseorang untuk melakukan hubungan suami istri.

c. Kekerasan Secara Psikologis, merupakan kekerasan yang dilakukan dengan penghinaan, merendahkan, mengekploitasi sehingga dapat mengakibatkan atau dampak yang ditimbulkan dari adanya kekerasan yaitu ancaman kekerasan.

d. Kekerasan Finansial kekerasan yang dilakukan dengan cara mengeksploitasi, manipulasi, mengendalikan korban untuk bekerja tetapi dengan cara yang tidak baik dan memaksa, tidak menafkahi, atau korban sama sekali tidak diberikan ruang utnuk bekerja namun menelantarkannya.

Terjadinya kekerasan dalam rumah tangga disebabkan oleh banyak hal. Ada beberapa faktor penyebab yang daapt memicu terjadinyan kekerasan dalam rumah tangga antara lain

1. Perselingkuhan, Dalam hal ini perselingkuhan yang dimaksud adalah perselingkuhan yang dilakukan oleh suami dengan perempuan lain ataupun suami menikah atau mempunyai istri lagi. Perselingkuhan ini juga menjadi salah satu faktor seseorang melakukan tindak kekerasan dalam rumah tangga.

2. Berbicara keras merupakan satu faktor yang harus di hindari, karena dapat memancing emosi pendengar karena merasa sakit hati, sehingga akan terjadi percekcokan. Sehingga antara suami dan istri harus mampu mengendalikan dan mengontrol emosi masing -masing. Karena emosi dapat memicu terjadinya kekerasan dalam rumah tangga.

3. Sifat Ego Salah satu penyebab terjadi nya kekerasan karena hanya ingin di dengarkan dan di ikuti maunya saja, sehingga membuat pasangan menjadi marah dan muncul lah perlakuan arogan dan semenah -menah terhadap istri/suami.

4. Ekonomi Faktor penyebab yang sangat sering terjadi dalam kasus kekerasan dalam rumah tangga, dalam artian bahwa jika keadaan ekonomi dalam suatu keluarga masih labil atau masih belum mencukupi, maka setiap salah satu menginginkan sesuatu dan kebutuhan itu tidak terpenuhi disnilah akan muncul pertengkaran dan tidak bisa dipungkiri bisa terjadi kekerasan di dalamnya.

5. Kekerasan Sebagai Alat Untuk Menyelesaiakan Konflik. Faktor ini merupakan faktor juga sangat mempengaruhi, ketika ada kesalahpahaman, atau tidak tercapainya keinginan suami terhadap istri, bisa saja laki-laki yang cenderung memiliki kekuatan fisik diatas lebih kuat dari pada perempuan, menggunakan kekuatan fisiknya untuk melukai, memukul istri agar mematuhi apa yang menajdi keinginannya.

Selain kekerasan dalam rumah tangga menimbulkan berbagai persoalan permasalahan pada anak. Dalam jangka pendek seperti ancaman terhadap keselamatan hidup anak, merusak struktur keluarga, munculnya berbagai gangguan mental. Sedangkan dalam jangka panjang memunculkan potensi anak terlibat dalam perilaku kekerasan dan pelecehan di masa depan, baik sebagai pelaku ataupun sebagai korban.

Pola asuh dalam keluarga bisa memberikan sumbangan dalam membentuk kekerasan. Pola asuh yang paling mendukung untuk terjadinya kekerasan dalam rumah tangga kelak adalah pola asuh otoriter. Pola asuh otoriter dalam penerapannya merupakan pola asuh yang keras, menekankan kedispilinan yang tinggi, pemaksaan kehendak orang tua kepada anak, selalu memberikan hukuman terhadap kesalahan yang dilakukan. Hal ini menjadikan anak memiliki sifat yang temperamental, tidak senang, tidak memiliki tujuan, penuh ketakutan, mudah stres, menarik diri, dan tidak percaya terhadap orang lain. Banyak orang tua beranggapan pola asuh otoriter pada anak adalah hal wajar sebagai cara mendisiplinkan anak. Padahal anak yang mendapatkan perlakuan dan asuhan yang keras dan tanpa afeksi, akan mengakibatkan luka batin pada anak.

\section{Pelaksanaan Kegiatan Pengabdian}

Kegiatan pengabdian kepada masyarakat yang dilakukan pada Pulau Seram dilaksanakan atas koordinasi dengan pemerintah setempat. Setelah melakukan koordinasi antara pemerintah desa, kemudian dilakukan identifikasi permasalahan yang sering dihadapi oleh masyarakat. 
Setelah melakukan identifikasi awal berdasarkan data yang diperoleh dari koordinasi bersama pemerintah desa di pulau seram, maka direncanakan kegiatan pengabdian masyarakat pada tanggal 23 April 2021. Setelah dilakukan kegiatan mewujudkan kesadaran hukum terhadap kekerasan bagi perempuan dan anak melalui penyuluhan yang diberikan masyarakat setempat di Pulau Seram, ditemukan bahwa kekerasan yang terjadi kepada perempuan dan anak mengalami peningkatan disebabkan oleh faktor-faktor yang melatarbelakangi terjadinya kekerasan. Oleh karena itu dibutuhkan penanganan dari pemerintah untuk menanggulangi tindak pidana kekerasan tersebut.

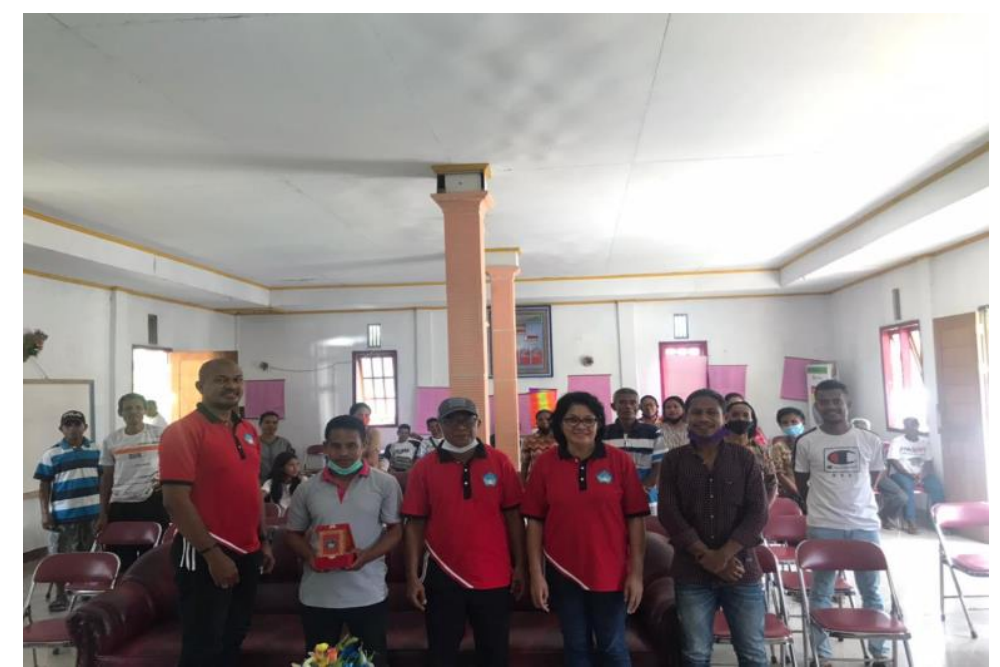

Gambar 1: Kegiatan Penyuluhan Kesadaran Hukum terhadap kekerasan dalam rumah tangga bagi perempuan dan anak

\section{SIMPULAN}

Berdasarkan kegiatan Pengabdian Masyarakat yang dilakukan dipulau seram dapat disimpulkan bahwa kasus kekerasan dalam rumah tangga yang terjadi kepada perempuan dan anak mengalami peningkatan. Selain itu kekerasan dalam rumah tangga bagi perempuan dan anak dilatarbelakangi oleh beberapa faktor serta upaya pemerintah dalam menanggulangi tindak pidana kekerasan dalam masyarakat.

\section{SARAN}

Kami berharap melalui kegiatan pengabdian masyarakat yang dilakukan di Pulau Seram dapat memberikan pemahaman tentang kesadaran hukum terhadap kekerasan yang terjadi dalam rumah tangga baik kepada perempuan maupun anak.

\section{UCAPAN TERIMA KASIH}

Pada kesempatan ini, kami ingin menyampaikan terima kasih kepada Dekan Fakultas Hukum Universitas Pattimura yang telah mengijinkan kami untuk berbagi ilmu dengan masyarakat di Pulau Seram.

\section{DAFTAR PUSTAKA}

Fatahillah A Syukur, (2011), Mediasi Perkara KDRT (Kekerasan Dalam Rumah Tangga) Teori dan Praktek Di Pengadilan Indonesia, Bandung: CV. Mandar Maju.

Moerti Hardiati Soeroso. (2010). Kekerasan Dalam Rumah Tangga Dalam Perspektif YuridisViktimologis, Jakarta: Sinar Grafika Offset.

Sulaeman, M. (2019). Kekerasan terhadap perempuan: Tinjauan dalam berbagai disiplin ilmu \& kasus kekerasan. Bandung: Refika Aditama

Soedarto. (1977). Hukum dan hukum pidana. Bandung: Alumni Bandung.

Soerjono Soekanto, (1982), Kesadaran Hukum dan Kepatuhan Hukum, Jakarta: CV Rajawali. 